\title{
Medical Statistics, Patronage and the State: The Development of the MRC Statistical Unit, 1911-1948
}

\author{
EDWARD HIGGS*
}

The development of medical statistics based on the concepts of probability and error-theory developed by Francis Galton, Karl Pearson, George Udny Yule, R A Fisher, and their colleagues, has had a profound impact on medical science in the present century. This has been associated especially with the activities of the Medical Research Council (MRC) Statistical Unit at the London School of Hygiene and Tropical Medicine (LSHTM). It was here in 1946 that the world's first statistically rigorous clinical trial was undertaken, and where in the 1950s Austin Bradford Hill and Richard Doll revealed a statistical relationship between smoking and lungcancer. But how and why was this key institution founded, and why were its methods probabilistic?'

One might assume that the sheer brilliance of the work produced by Pearson and his statistical followers was sufficient to win over the medical profession, and to attract funding for the MRC Unit. However, one might question the extent to which an association with Pearson, and with the mathematical technicalities of his statistics, immediately endeared the fledgling discipline of biostatistics to the medical community. As J Rosser Matthews has shown recently, Pearsonian statistics were only haltingly accepted by medical scientists in Britain in the 1920s and 1930s, and were little understood by medical practitioners. ${ }^{2}$ How then was such a university-based infrastructure for medical statistics established? Ultimately, of course, the Statistical

\begin{abstract}
* Edward Higgs, DPhil, Department of History, University of Essex, Wivenhoe Park, Colchester, CO4 3SQ.
\end{abstract}

The research for this article was undertaken whilst the author was a lecturer at the University of Exeter under the Wellcome Trust University Award scheme. The author wishes to express his thanks for help in revising an original draft of this article given by W F Bynum, Eileen

Magnello, and anonymous referees.

${ }^{1}$ For the 1946 clinical trial, see J R Matthews, Quantification and the quest for medical certainty, Princeton University Press, 1995, pp. 115-40. For the statistical work on smoking, see V Berridge, 'Science and policy: the case of postwar British smoking policy', in S Lock, L A Reynolds, E M Tansey (eds), Ashes to ashes, Amsterdam, Rodopi, 1998, pp. 150-71; D Collingridge and C Reeve, Science speaks to power, London, Pinter, 1986, pp. 123-44; R Doll and A B Hill, 'Smoking and carcinoma of the lung', Br. med. J., 1950, ii: 739-48; R Doll and A B Hill, 'A study of the aetiology of carcinoma of the lung', Br. med. $J$., 1952, ii: 1271-86; R Doll and A B Hill, 'Lung cancer and other causes of death in relation to smoking', Br. med. J., 1956, ii: 1071-81.

${ }^{2}$ Matthews, op. cit., note 1 above, pp. 115-30. 


\section{Edward Higgs}

Unit depended upon the MRC and the Ministry of Health for the funding. ${ }^{3}$ However, if one is to believe scholars such as Roger Davidson, the early twentieth century was a period when the narrow requirements of an administrative elite of civil servants dedicated to preserving the status quo, and eager not to baffle politicians with unfamiliar methods of analysis, acted as a brake on the development of statistical work within government. ${ }^{4}$ Why then did the MRC Statistical Unit at the LSHTM gain such financial support?

The background to this development is plainly the rise of specialization in medicine, ${ }^{5}$ and the creation of university medical departments as the powerhouses of medical research. The latter gave aspiring medical professionals an enviable degree of recognition and financial security in an often difficult health-care market. ${ }^{6}$ But the crucial question here is why this particular specialism in this particular place? Much of the story to be told concerns the career of Major Greenwood, the first director of the Statistical Unit from 1927 to 1945, and the key figure in the development of the profession of medical biostatistics in the inter-war period. Greenwood has recently been described as "one of the founders of the modern approach to epidemiology", 7 and his championing of the use of Pearsonian statistics in debates within medical science has been noted by Matthews. ${ }^{8}$ Greenwood was, of course, building here on the long tradition in Britain of the use of statistical methods, if of a non-probabilistic variety, in the analysis of how diseases behave. One might point here to the epidemiological work of William Farr in the Victorian General Register Office (GRO), and of Arthur Newsholme in the Local Government Board (LGB) of the early twentieth century. ${ }^{9}$ Greenwood also had the gift of communicating the results of statistically-based epidemiology in a clear, untechnical language which was accessible to a mathematically unsophisticated medical community. ${ }^{10}$ But, in addition, Greenwood was also adept at using official networks of patronage and

\footnotetext{
${ }^{3}$ Public Record Office, London (hereafter PRO) FD 2/14 Medical Research Council (hereafter MRC): Annual reports: Annual report of the MRC for the year 1927-1928, p. 132; PRO FD 1/7107 MRC: Files: Statistical Committee: Establishment and Correspondence: Memorandum of 15 March 1927 entitled 'Statistical work for the council', and memorandum from Greenwood to Fletcher of 24 March 1927; PRO FD 2/22, Annual report of the MRC for the year 1935-1936, pp. 135-6.

${ }^{4} \mathrm{R}$ Davidson, Whitehall and the labour problem in late-Victorian and Edwardian Britain, London, Croom Helm, 1985.

${ }^{5}$ See, for example, G Rosen, Specialization of medicine, New York, Froben Press, 1944; R Stevens, Medical practice in modern England: the impact of specialization and state medicine, New Haven, Yale University Press, 1966; L Granshaw, "Fame and fortune by means of bricks and mortar": the medical profession and specialist hospitals in Britain, 1800-1948', in L Granshaw and R Porter (eds), The hospital in history,
}

London, Routledge, 1989, pp. 199-220.

${ }^{6} \mathrm{~S}$ V F Butler, 'A transformation in training: the formation of university medical faculties in Manchester, Leeds, and Liverpool, 1870-84', Med. Hist., 1986, 30: 115-32.

${ }^{7} \mathrm{~L}$ Wilkinson, 'Epidemiology', in W F Bynum and R Porter (eds), Companion encyclopedia of the history of medicine, London, Routledge, 1997, vol. 2, pp. 1262-82, on p. 1262.

${ }^{8}$ Matthews, op. cit., note 1 above, pp. 86-130.

${ }^{9} \mathrm{~J}$ M Eyler, Victorian social medicine: the ideas and methods of William Farr, London, Johns Hopkins University Press, 1979, pp. 97-122; J M Eyler, Sir Arthur Newsholme and state medicine, 1885-1935, Cambridge University Press, 1997.

${ }^{10} \mathrm{M}$ E Magnello, 'The introduction of mathematical statistics into medical research: the roles of Karl Pearson, Major Greenwood and Austin Bradford Hill', in M E Magnello and A Hardy (eds), Measuring health: quantification and statistics in the history of medicine, Amsterdam, Rodopi, forthcoming. 
support for building up the institutional base of medical statistics, and this will be the focus of the present paper. Institutions matter in intellectual life, and they are not solely the by-product of the generation of good ideas. It will be shown below how Greenwood's development of the MRC Statistical Unit reflected both the workings of personal networks of patronage and influence, and the interpenetration of state and academic science in the twentieth century. The latter has been extensively examined but usually from the point of view of how science impacts, or fails to impact, upon government. ${ }^{11}$ This paper will be concerned more with how scientists could use the various organs of the state for the furtherance of their own institutional and career goals. In this Greenwood plainly showed personal ambition, and at times even ruthlessness, but his activities should not be seen simply in terms of personal aggrandisement. He believed that his discipline had much to offer medical science, and that he was in a position to foster its development.

\section{The Foundations of Pearsonian Medical Statistics}

The discipline of Pearsonian medical statistics grew, of course, out of the activities of Karl Pearson himself. There has been a tendency to conflate Pearson's statistical innovations and his belief in eugenics ${ }^{12}$ but, as Eileen Magnello has shown, Pearson's work on eugenics formed only a small part of his scientific activity, and absorbed comparatively little of the time of the staff of the various laboratories he established at University College London. Most of Pearson's effort went into the Biometric Laboratory supported by the Worshipful Company of Drapers, rather than into the Eugenics Laboratory funded out of Francis Galton's estate. It was in the former, mainly concerned with the application of statistics to biology and the mechanics of evolution, that Pearson developed his new mathematical approach, whilst the work of the Eugenics Laboratory was mainly based on an analysis of family pedigrees and actuarial death rates. ${ }^{13}$ But even in the latter much work was undertaken on epidemiological issues only tangentially linked to heredity or dysgenic characteristics by the Laboratory's medical officer, Percy Stocks. ${ }^{14}$

\footnotetext{
${ }^{11}$ See, for example, M Gowing, Science and politics, London, J W Ruddock, 1977; P Gummett, Scientists in Whitehall, Manchester University Press, 1980; W McGucken, Scientists, society, and the state: the social relations of science movement in Britain, 1931-1947, Columbus, Ohio State University Press, 1984, pp. 155-264; J

Ronayne, Science in government, London, Edward Arnold, 1984, pp. 10-12, 16-18;

Collingridge and Reeve, op. cit., note 1 above; $A$ Barker and B G Peters (eds), The politics of expert advice, Edinburgh University Press, 1993.

${ }^{12}$ For the conflation of statistics and eugenics see, for example, D Mackenzie, Statistics in Britain, 1865-1930, Edinburgh University Press, 1981, pp. 73-93.

${ }^{13} \mathrm{M}$ E Magnello, 'The non-correlation of biometrics and eugenics: rival forms of laboratory
}

work in Karl Pearson's career at University College London', Hist. Sci., forthcoming.

${ }^{14}$ In the period 1928 to 1932 , for example, Stocks published the following articles in the Galton Laboratory's Annals of Eugenics: 'Fresh evidence on the inheritance factor in tuberculosis', Ann. Eugenics, 1928, 3: 84-95; 'Infant mortality in the metropolitan boroughs in relation to occupation', Ann. Eugenics, 1928, 3: 194-200; 'A study of the epidemiology of measles', Ann. Eugenics, 1928, 3: 361-98; 'The distribution of cancer and tuberculosis mortality in England and Wales', Ann. Eugenics, 1930-31, 4: 341-61; 'On the spread of small-pox in partially vaccinated communities', Ann. Eugenics, 1932, 5: 302-10. 


\section{Edward Higgs}

Pearson's work and his Biometric and Eugenic Laboratories were the training ground for numerous men and women who subsequently went on to become key participants in the emergence of the discipline of medical statistics in Britain. Amongst these, two men were of especial importance in the early history of the MRC Statistical Unit, George Udny Yule (1871-1951) and Major Greenwood (1880-1949). Yule was in many ways the more distinguished of the two. Having originally studied civil engineering in Pearson's department at University College, he became a demonstrator to Pearson in 1893 and was promoted within UCL to the post of assistant professor of statistics in 1896. In 1912 Yule moved to Cambridge to take up the newly established university lectureship in statistics, staying there until his death in 1951. He made major contributions to the theory of regression and correlation analysis, and in the fields of Mendelian inheritance, the statistical analysis of language, and epidemiology. ${ }^{15}$

According to Lancelot Hogben, Greenwood was so fired by reading Pearson's Grammar of science whilst still a medical student at the London Hospital, that he decided to devote himself to biometrics. He made contact with Pearson and studied under him at University College during the academic year 1904/5. Greenwood then went on to take up a research scholarship from the British Medical Association in 1905 , and became the demonstrator in the physiological laboratory of Leonard Hill at the London Hospital Medical School. In 1910 he was appointed statistician at the Lister Institute of Preventative Medicine, and began a distinguished career in medical statistics, particularly in epidemiology and public health. ${ }^{16}$ Greenwood's engaging, if occasionally barbed, personality shines through much of his correspondence.

But despite the importance of Pearson's institutional base at UCL it is unlikely that this would have provided a firm grounding for the institutional development of medical statistics. This partly reflected the fragility of the funding of Pearson's laboratories and his somewhat irascible nature. As Greenwood confided to Walter Fletcher, the secretary of the MRC, in 1920, "Pearson is desperately hard up. His institute is half empty ... He is 64 , has quarrelled with nearly everyone over 40 and is ending his career almost alone." ${ }^{17}$ The medical work of Pearson's laboratories was also always overshadowed by his central interests in evolutionary biology, botany, zoology, and physical anthropology. ${ }^{18}$

Given the paucity of university posts for medical statisticians, and the achievements of Victorian public medicine, it was understandable that Greenwood should look to the state for support. The main "interface" between the latter and the medical scientific community was the newly formed MRC. This had been set up under the

${ }^{15}$ Dictionary of national biography 1951-1960, ed. E T Williams and H M Palmer, Oxford University Press, 1972, pp. 1095-6.

${ }^{16}$ L Hogben, 'Major Greenwood', Obituary notices of fellows of the Royal Society, vol. VII, 1950-51, London, Royal Society, 1951, pp. 139-54; Matthews, op. cit., note 1 above, p. 104; Mackenzie, op. cit., note 12 above, pp. 110-11. He was also responsible for some pioneering work in medical history: M Greenwood, The medical dictator, and other biographical studies, London, William and Norgate, 1936.

${ }^{17}$ PRO, FD 5/91 MRC: Files: Professor Major Greenwood: appointment, funding for research: letter from Greenwood to Fletcher of 21 July 1920.

${ }^{18}$ Magnello, op. cit., note 13 above. 
clause of the 1911 National Insurance Act which provided for a levy on contributions to the national health insurance scheme for the purposes of undertaking medical research. ${ }^{19}$ Due to the influence of members of the medical profession, especially Christopher Addison, a former professor of anatomy and later Liberal MP and Minister of Health, the MRC was not subordinated to a government department, as in the case of the GRO, but given a block grant from the Treasury to disburse as it saw fit. ${ }^{20}$ The Council's grant rose from $£ 53,000$ in 1914 to $£ 195,000$ in $1939 .{ }^{21}$ Under Sir Walter Fletcher (1873-1933), its first secretary from 1914 to 1933 and a pioneering medical scientist in his own right, it was oriented towards the academic pursuit of knowledge, rather than the servicing of government policy making. As will be argued here, however, this did not mean that the MRC was averse to working closely with the Ministry of Health. The creation of such a unique institution, the forerunner of later research councils, gave Britain a medical research infrastructure of international significance. In the furtherance of medical science, the MRC undertook its own investigations but also funded similar activities in universities and hospitals. ${ }^{22}$ It established a National Institute for Medical Research in 1914, made up of three departments of experimental research (bacteriology, biochemistry and pharmacology, and applied physiology), and a Statistical Department under John Brownlee. ${ }^{23}$

Brownlee was born in Scotland in 1868, and had a more traditional medical background than Greenwood. Educated at the University of Glasgow, where he studied mathematics and natural philosophy, he also obtained the degree of MD in 1898. He was subsequently a resident physician in various hospitals in Glasgow, and medical officer of health for Guernsey. Brownlee became increasingly interested in applying mathematical techniques to medical and biological problems, and was drawn into the circle of the Biometric School. ${ }^{24}$ His MRC department was intended

to consist of persons in the permanent employment of the scheme who will be engaged in enquiries relating to diet, occupation, habits of life and other matters bearing upon the incidence of disease, and who will collect and deal with all types of vital statistics including the distribution of disease, the relative frequency of special types of lesions in diseases such as tuberculosis, and in general with all statistical investigations useful either as preliminary to research or confirmatory of its results. ${ }^{25}$

This represented a vote of confidence in the new medical statistics on the part of the MRC. There is also some evidence that the MRC Statistical Department was envisaged as the means of undertaking inquiries into causes of excessive sickness under section 63 of the National Insurance Act. This allowed for the holding of enquiries to determine if excessive claims on the scheme were due to bad working

\footnotetext{
${ }^{19}$ A L Thomson, Half a century of medical research. Volume 1: Origins and policy of the Medical Research Council (UK), London, HMSO, 1973, pp. 11-21.

${ }^{20}$ Ibid., pp. 22-65.

${ }^{21}$ Ibid., pp. 191-4.

${ }^{22}$ For the MRC's research programme, see A

$\mathrm{L}$ Thomson, Half a century of medical research.
}

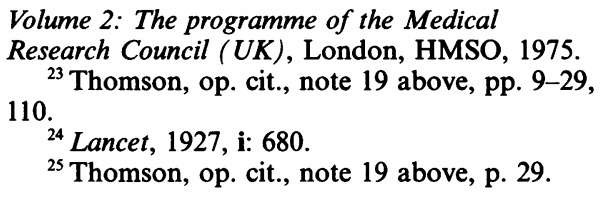

Volume 2: The programme of the Medical Research Council (UK), London, HMSO, 1975.

${ }^{23}$ Thomson, op. cit., note 19 above, pp. 9-29, 110.

${ }^{24}$ Lancet, 1927, i: 680 .

${ }^{25}$ Thomson, op. cit., note 19 above, p. 29. 


\section{Edward Higgs}

conditions, poor housing, or insanitary conditions, and for the excess to be recouped from culpable employers, landlords and local authorities. In practice this clause proved inoperative ${ }^{26}$ but the National Insurance Joint Committee, which administered the Act, certainly saw the need for statistical enquiries of this sort. ${ }^{27}$ The MRC's first annual report indicated that its Statistical Department would "probably have to consider and advise how the statistical material provided for under the Insurance Act should be dealt with" ${ }^{28}$ Significantly, the first special report published by the MRC was one by Brownlee on the excessive incidence of phthisis in the boot and shoe industry. ${ }^{29}$

But the MRC Statistical Department did not prosper under Brownlee. He was constitutionally unable to give sustained advice to his colleagues-indeed he appears to have been incapable of paying attention to anything for very long. ${ }^{30}$ In a letter to Fletcher of 1924, Yule describes a conversation with the "old thing":

Phew! there's an odd sort of fly which you often see in a garden on a hot day in summer: it seems to be nearly still, hovering over a rose-bush say, for seconds together, when suddenly flick! and the blessed fly is in quite a different position, and you can't think how in Hell it ever got there. I know that my mind sometimes seems to work like that, but Brownlee's is much worse. Place-names in Aberdeenshire and on the Black Sea, the occurrence of elephants in Scotland, the whisky-drinking habits of one of his mother's trustees, the price of Turner drawings, the existence of areas where illegitimacy seems to be the normal thing in Scotland ... you wouldn't think, would you? that so many subjects could arise really naturally out of a short conversation on the work of the Anthropometric Standards Committee?

This character trait might also explain Brownlee's inability to complete key publishing projects. $^{32}$

The establishment of the Statistical Department at the MRC's National Institute for Medical Research in 1914 was also followed shortly afterwards by the outbreak of the First World War. The statistical resources of the MRC were immediately placed at the disposal of the War Office with the aim of compiling statistics of the military sick and wounded. This was conceived as contributing to both medical science and the war effort, and was to be based on a systematic analysis of hospital registers and medical cards forwarded from the Front and convalescent hospitals to

\footnotetext{
${ }^{26}$ Eyler, Sir Arthur Newsholme, op. cit., note 9 above, p. 231.

${ }^{27}$ PRO ACT 1/1 Government Actuaries Department: Files: Memorandum on 'Statistics and returns'.

${ }^{28}$ PRO FD 2/1 First annual report of the MRC, 1914-1915 (Dated 18 October 1915), p. 6.

${ }^{29}$ PRO FD 4/1 MRC: Published reports: The first report of the special investigation committee upon the incidence of phthisis in relation to occupation. The boot and shoe industry.

${ }^{30}$ Thomson, op. cit., note 19 above, pp. 114-15.

${ }^{31}$ PRO FD 5/79 Letter from Yule to Fletcher 19 June 1924 . For equally unflattering comments
}

on Brownlee, see, PRO FD 5/91 Letter from Greenwood to Fletcher, 27 December 1922; PRO FD 1/7107 Letter from A Watson, the government actuary, to Fletcher, 8 April 1927.

${ }^{32}$ See, for example, his failure to complete a "compendium of statistical mathematics" for biologists and medical scientists which was promised in the annual reports of the MRC from 1922 till his death in 1927: PRO FD 2/9 Annual report of the MRC for 1922-23, p. 28; PRO FD 2/12 Annual report of the MRC for 1925-26, pp. 43-4. 
the MRC in London. ${ }^{33}$ What was assumed to be a relatively manageable task when hostilities were seen in terms of a short campaign became totally unwieldy in the circumstances of the extended butchery of the Great War. By 1919 the staff of the project's central statistical office numbered 225 and cost $£ 18,000$ annually. But this was considered insufficient for the analysis of the data collected, and it was estimated that if staffing was increased to 350 , at an annual cost of $£ 32,500$, the work could be completed in three years. Given that the entire government grant to the MRC in 1919 was only $£ 60,000,{ }^{34}$ the task was plainly beyond its resources. In 1920 the Ministry of Pensions took over the whole statistical organization from the Council, as well as the responsibility for the completion of the statistical information required for a proposed volume on the medical statistics of the war. The Ministry was primarily concerned with using the data gathered for war pension purposes, and it was not until 1931 that an official history based on the material collected was published. ${ }^{35}$ The MRC had expended a large sum of money and considerable effort on statistical work, and had very little to show for it. ${ }^{36}$

\section{The Rise of Major Greenwood}

The new quantitative methods were also making their way into the established statistical apparatus of the state. This can be seen in the case of the GRO, which since the days of Farr in the mid-nineteenth century had been collecting and analysing mortality and cause of death data gathered via the civil registration system. Sir Bernard Mallet, the Registrar General, was aware that the GRO lacked expertise in the new Pearsonian statistics. As a consequence, the Office sought permission from the Treasury in December 1911 to employ outside experts to give "advice on matters connected with recent developments in the mathematical treatment of statistics ...". ${ }^{37}$ The following month Mallet was asking for authority to pay "Edny Ule" and E C Snow $£ 50$ for such advice. ${ }^{38}$ In March 1912 both Yule and Edwin Cannon, the economist, attended a conference at the GRO "on the reform of the population tables". ${ }^{39}$ The Office was also limited in its investigations by being confined to the analysis of one source of data-death certificates. In his report on the incidence of phthisis in the boot and shoe industry, Brownlee criticized the data provided by the

\footnotetext{
${ }^{33}$ PRO FD 2/1 First annual report of the MRC, 1914-1915, pp. 20-1; PRO FD 2/2 Second annual report of the MRC, 1915-1916, pp. 26-9.

${ }^{34}$ Thomson, op. cit., note 19 above, p. 191.

${ }^{35} \mathrm{~T} \mathrm{~J}$ Mitchell and G M Smith, History of the Great War based on official documents. Medical services: casualties and medical statistics of the Great War, London, HMSO, 1931, pp. ix-xiii. A selection of the original medical records can be found in PRO MH 106: 1914-1918 War: Representative Medical Records.

${ }^{36}$ All that came out of this vast effort in the short term were a few papers in the MRC's Statistical Reports series: A W Ormond, 'An analysis of 8,670 ophthalmic cases treated at a
}

\author{
home hospital', January 1919, No. 3; J M \\ Fortescue-Bricklade, 'Statistical and clinical \\ report on 600 cases of gunshot wound of the \\ chest', February 1919, No. 4; W L Mann, A B \\ Soltau and T R Elliot, 'Statistical reports from \\ the British Forces in France on penetrating \\ wounds of the chest', June 1919, No. 5. \\ ${ }^{37}$ PRO RG 29/4 General Register Office \\ (hereafter GRO): Letter Books: Out Letter Book \\ 1907-1912, pp. 191-2. \\ ${ }^{38}$ Ibid., p. 199; PRO RG 29/8 In Office Letter \\ Book 1908-1912, p. 71. \\ ${ }^{39}$ PRO RG 29/4 GRO: Letter Books: Out \\ Letter Book 1907-1912, p. 212.
}




\section{Edward Higgs}

GRO. He argued that the census classification "shoemaker" was inconsistent, whilst the tendency for sick shoemakers to drop out of the trade, and for their deaths to be registered under other occupations, undermined the validity of the GRO's age specific mortality rates for the industry. He reworked the GRO's figures, and then used these in conjunction with information drawn from the National Union of Boot and Shoe Operatives, and from the medical officers of health in Leicester and Northampton, to produce his report. ${ }^{40}$

The limitations in the GRO's statistical apparatus were highlighted in the immediate aftermath of the First World War, when, in 1919, the Office was brought under the direct control of the newly formed Ministry of Health. The Ministry believed that the GRO and its Statistical Department should be directly subordinated to the policy requirements of the Ministry. In order to achieve this, one of the Ministry's assistant secretaries, Sylvanus Vivian, was placed in the GRO as deputy Registrar General but with almost unlimited authority to reform its organization. Mallet resigned in protest and Vivian became the head of the Office at the beginning of 1921. Vivian believed that the statistical role of the GRO should be to provide data for the Ministry's purposes, rather than to initiate scientific investigation of its own. ${ }^{41}$

There was, however, a general feeling within the Ministry that the GRO's Statistical Department was not qualified to undertake the tasks to be placed upon it. In January 1920, Vivian declared that in his opinion, "the fact has clearly emerged that the GRO has never been equipped, and was never intended to be equipped, with an establishment suitable for dealing with the more responsible aspects of its work". ${ }^{42}$ In June 1920 the Ministry was complaining to the Treasury that delays in the production of statistical reports made it obvious, "that the present professional staff is not adequate to perform even the normal statistical work which devolves upon it ...". ${ }^{43}$ But how was this deficiency to be made good-by strengthening the GRO, or by absorbing it into a central statistical department within Health?

One of the officers within the Ministry advocating the latter course was Major Greenwood. ${ }^{44}$ In comparison to Brownlee, Greenwood had had a much greater impact on the war effort. He had been seconded from the Lister Institute to the Ministry of Munitions in 1917 to undertake statistical work for the Health of Munitions Workers Committee. This had been set up in 1915 to investigate the hygienic conditions in munitions factories but gradually came to focus on the best means of securing the maximum efficiency from munitions workers. ${ }^{45}$ Greenwood's contribution to the committee's work was to create "industrial life tables" showing

${ }^{40}$ PRO FD 4/1 MRC: Published reports.

${ }^{41}$ PRO MH 78/114 Ministry of Health:

Establishment and Organisation Files: Coordination of work with Ministry of Health and appointment of Registrar General.

${ }^{42}$ PRO RG 20/80 GRO: Establishment Files: Organisation and Staffing: memo. from Vivian to Morant, 19 January.

${ }^{43}$ PRO T 162/1 Treasury: Establishment Files: Health Ministry: Registrar General's Department Reorganisation (Higher Staff): letter of 7 June 1920.

\footnotetext{
${ }^{44}$ PRO RG 20/83 Creation of a Department of Vital and Medical Statistics: memo. by Greenwood, November 1919.

${ }^{45}$ PRO FD 5/37 Ministry of Munitions, Health of Munitions Workers (Fatigue) Committee: reports; correspondence with MRC, 1914-1918; H Jones, 'Industrial health research under the MRC', in J Austoker and L Bryder (eds), Historical perspectives on the role of the $M R C$, Oxford University Press, 1989, pp. 137-62.
} 
how many workers joining various industries were still being employed in them after set periods of time. He concluded that although wastage was great, much of it was inexplicable, or at least unexplained, although he pointed to the greater turnover of married women with children. This he put down to their insufficient "reserves of energy to meet the double demand upon them" ${ }^{46}$ This interest in industrial efficiency survived the war with the establishment of the Industrial Fatigue Research Board, a joint venture by the MRC and the newly created Department of Scientific and Industrial Research, with active interest shown by the Home Office, Ministry of Reconstruction, Post Office and the Coal Commission. ${ }^{47}$ The science of statistics was being mobilized in the service of total war and state intervention in economic affairs.

At Munitions Greenwood came into contact with Walter Fletcher, who had sat on the Munitions Workers Committee since its foundation..$^{48}$ Fletcher was plainly impressed by Greenwood, and the MRC undertook to provide him with administrative assistance, and eventually published his research in its report series. ${ }^{49}$ This support continued when Greenwood moved from Munitions to the Ministry of Health in 1919. Fletcher and Greenwood struck up a close personal friendship which was to last until Fletcher's death in 1933. They dined together at their clubs, and corresponded frequently-Greenwood obtaining career advice, and Fletcher using Greenwood as a sounding-board for his ideas on the policy and development of the MRC..$^{50}$ Something of the warmth of this relationship can be gauged by the outcome of a disagreement the two men had in 1931 over the role of the Ministry of Health in spreading public information on the new nutritional knowledge currently being amassed by the MRC. Fletcher argued strongly that Health was not playing a powerful enough propaganda role, whilst Greenwood was equally strident in defending the Ministry. After falling out, the two friends made up, Greenwood writing touchingly that, "I really care but little for intellectual rights and wrongs, outside of working hours. I care a great deal for human friendship at all hours. I am very sorry I hurt you." Fletcher went still further and declared Greenwood's arguments would have made "me cross if I did not love you so much". ${ }^{51}$ Given Fletcher's key importance during the early decades of the twentieth century in allocating funding and prestigious official positions in the medical sciences, Greenwood's close relationship with him was of signal importance in the forwarding of the statistician's career and of medical statistics in general..$^{52}$

It was in the context of this friendship that Greenwood discussed his career options

\footnotetext{
${ }^{46}$ PRO FD 4/16 A report on the causes of wastage of labour in munitions factories employing women. MRC Special Report Series, No. 16 (1918).

${ }^{47}$ PRO FD 5/39 Industrial Fatigue Research Board: correspondence with MRC; financial projections and request for funding, 1920.

${ }^{48}$ PRO FD 5/37 Ministry of Munitions, Health of Munitions Workers (Fatigue) Committee: reports; correspondence with MRC, 1914-1918.

${ }^{49}$ PRO FD 5/38, Ministry of Munitions, Health of Munitions Workers (Fatigue)
}

Committee: reports; correspondence with MRC, 1916-1918, letter of 27 December 1916. ${ }^{50}$ PRO FD 5/91 MRC: Files.

${ }^{51}$ PRO FD 5/92 Professor Major Greenwood: Research Interests: letters from Fletcher to Greenwood of 2 November 1931, and of Greenwood to Fletcher of 18 November 1931.

${ }^{52}$ For Greenwood's appreciation of the importance of Fletcher's role, see M F Fletcher, The bright countenance: a personal biography of Walter Morley Fletcher, London, Hodder and Stoughton, 1957, pp. 286-7. 


\section{Edward Higgs}

with Fletcher in April 1919. Like many others at the time, Greenwood had seen the new Ministry of Health, which brought together the fragmented responsibilities of the state for health, as an opportunity to extend and broaden the medical work of the LGB..$^{53}$ Although Greenwood may have hoped that the Ministry would continue the Board's epidemiological research, and thus give an outlet for his statistical abilities, he came to feel that neither the governing body of the Lister Institute nor the Ministry of Health had any interest in the application of statistical methods to medicine. He therefore asked Fletcher if the MRC could support him in some way. ${ }^{54}$ By June 1920, Fletcher had persuaded the Ministry to allow Greenwood to move to the MRC's Institute in Hampstead whilst remaining on its payroll. This was sold to the Ministry in terms of allowing Greenwood and Brownlee to share accommodation and calculating machines, and preventing duplication of effort between the two statisticians. ${ }^{55}$ Greenwood could also continue his work on industrial wastage by joining the Industrial Fatigue Research Board. ${ }^{56}$ In addition, it was envisaged that Greenwood would be able to help his old superior, Leonard Hill, who was now the head of the MRC's Department of Applied Physiology. ${ }^{57}$

However, other, more tactical, considerations also lay behind Greenwood's move. On the Ministry's side, Sir George Newman, the chief medical officer, was keen for someone to keep an eye on Hill. Newman had been incensed by the latter's participation in a deputation of birth control advocates ("French-letter evangelists" as Greenwood described them) to see the minister of health. ${ }^{58}$ Greenwood had a deep affection for Hill but also saw the opportunity for career advancement, for as he explained to Fletcher at the time:

What God really meant me to do, was first to move to Hampstead and valet old Hill for a few years at the same time developing a little training centre in statistico-physiologicoindustrial work at Cambridge to prevent the young hopefuls of the Industrial Fatigue Board wasting so much of their own and other people's time (and money) over crudities. Then when old Hill retires, you can quietly close down his department and I can transfer my headquarters to Cambridge. ${ }^{59}$

Developments in the relationship between Health and the GRO were also adding a sense of urgency to Greenwood's plans. Rather than absorbing the GRO's Statistical Department into the Ministry, senior management at Health had decided to strengthen the Office's skills base. In the summer of 1920, therefore, Vivian offered the post of "super-statistician" in the GRO to Udny Yule, who turned it down. ${ }^{60}$ Newman and

\footnotetext{
${ }^{53} \mathrm{C}$ Bellamy, Administering central-local relations, 1871-1919: the Local Government Board in its fiscal and cultural context, Manchester University Press, 1988, pp. 237-52; Frank Honigsbaum, The struggle for the Ministry of Health, London, Bell, 1970, pp. 20-3; Eyler, Sir Arthur Newsholme, op. cit., note 9 above, pp. 316-33.

${ }^{54}$ PRO FD 5/91 Letter from Greenwood to Fletcher of 7 April 1919; letter from Greenwood to Fletcher of 23 March 1920.

${ }^{55}$ Ibid. Memo from Buchanan to Newman of 19 June 1920.
}

\footnotetext{
${ }^{56}$ Ibid. Unsigned letter of 29 June 1920; Sixth Annual Report of the Medical Research Committee, 1919-1920, PP 1920, XXI (Cmd. 1088.), p. 90.

${ }^{57}$ PRO FD 5/91 Unsigned letter of 29 June 1920.

${ }^{58}$ Ibid. Letter of 21 July 1920 from Greenwood to Fletcher.

${ }^{59}$ Ibid. Letter from Greenwood to Fletcher of 13 July 1920.

${ }^{60}$ Ibid. Letter from Greenwood to Fletcher of 17 June 1920.
} 
Vivian then decided that Greenwood should be transferred to the GRO as a "statistical 'superman' to undertake the professional supervision of the professional statistical staff of the Department" ${ }^{61}$ Greenwood thought this was not a serious proposal until Christopher Addison, the minister, asked him at a ministry party when he was moving to the GRO. Greenwood was horrified, for, as he complained to Fletcher, as soon as "I pass under Vivian my scientific usefulness ceases" ${ }^{62}$ The collection and presentation of mortality data would give little scope for the application of his statistical skills, nor would it enable him to engage in epidemiological research. He decamped to the MRC Institute at Hampstead soon afterwards.

Greenwood's move also gave Fletcher a means of dealing with his problems with Brownlee. In the early 1920 s Fletcher set up a Statistical Committee to direct activities in the field of medical statistics on which the MRC would be represented by Brownlee, along with expert members from Health, other government departments, and universities. ${ }^{63}$ As Joan Austoker has noted, Fletcher liked to work by fostering small select committees which formed a scientific elite, and which "were able to exert control through the selective support of certain individuals and areas of research at the expense of others." She points to the MRC's Radiological, Hormones, Human Nutrition, Bacteriological, and Human Genetics Committees, as examples of this strategy. ${ }^{64}$ Originally Fletcher wanted Karl Pearson to chair the Statistical Committee but Pearson declined because of the work involved, and Greenwood was appointed instead. ${ }^{65}$

The Statistical Committee in its various forms acquired a staff of its own and began helping other MRC bodies, Whitehall departments, and university researchers with their statistics - part of the task which Brownlee had originally been set. ${ }^{66} \mathrm{By}$ 1925 Fletcher was writing to Newman noting that,

We are finding the Statistical Committee more and more useful every month ... It is in fact a medical statistical committee, not only interdepartmental but really national. We find this Committee simply invaluable, and I have little doubt that, whether directly or indirectly, they are useful to your Ministry. ${ }^{67}$

By the end of 1926 Greenwood had persuaded Newman to agree to complete interchangeability between work done by the Statistical Committee and by the Ministry of Health. ${ }^{68}$ Gradually, the Statistical Department was being overshadowed by Greenwood's Committee, and aspiring young statisticians such as Austin Bradford

\footnotetext{
${ }^{61}$ PRO RG 50/4 GRO Correspondence and Papers: Proposed Consultative Committee on Statistics 1920-21: Electoral Division of the Ministry Of Health: undated memo.

${ }^{62}$ PRO FD 5/91 Letter from Greenwood to Fletcher of 17 June 1920.

${ }^{63}$ PRO FD 1/7114 Committee on Industrial Health Statistics: Industrial Fatigue Research Board: memo. from Fletcher to the MRC Council dated 9 February 1923.

${ }^{64} \mathrm{~J}$ Austoker, 'Walter Morley Fletcher and the origins of basic biomedical research policy', in Austoker and Bryder (eds), op. cit., note 45 above, p. 27.
}

\footnotetext{
${ }^{65}$ PRO FD 1/7114 Letters from Fletcher to Pearson of 29 March 1921, and from Pearson to Fletcher of 31 March 1921.

${ }^{66}$ PRO FD 2/7 Report of the Medical Research Council, 1920-1921, p. 98; PRO FD 2/10 Report of the Medical Research Council, 1923-1924, pp. 115-16.

${ }^{67}$ PRO FD 1/7107 Letter from Fletcher to Newman of 8 June 1925.

${ }^{68}$ Ibid. Extract from the Statistical

Committee's minutes of 21 December 1926.
} 


\section{Edward Higgs}

Hill, Leonard Hill's son, found Greenwood a willing patron. ${ }^{69}$ Even though he sat on the Committee, Brownlee had little influence there, since all the work was done by a small inner circle of Greenwood's friends, especially Yule and Leon Isserlis. ${ }^{70}$ Isserlis was particularly beholden to Greenwood since the latter had persuaded Fletcher to support Isserlis's research on the grounds that

He was a major scholar of Trinity, a wrangler and a London D.Sc (pupil of Karl Pearson) and is one of the three or four best living mathematical statisticians ... and the author of several important papers. He is, however, a Russian Jew and although he was at an English public school and university, is sufficiently foreign in accent and appearance to be a very unlikely appointee to a good teaching post. ${ }^{71}$

Brownlee may have felt the awkwardness of his position because by the end of 1922 he was considering taking up an offer of the post of professor of public health at the University of Glasgow. His roots were in Scotland, of course, and a university post would confer considerable independence. On being told this news by Greenwood, Fletcher declared it "a bright ray of light for the New Year", although Greenwood thought that it was difficult, "to bring oneself to believe that any body of electors having the interest of education before their eyes could appoint Brownlee to profess anything". ${ }^{72}$ In the event Brownlee did not go and it was increasingly Greenwood who became restive, caught between the competing demands of the Lister Institute, to which he was notionally still bound, the Ministry of Health which paid his wages, and the MRC with which his loyalties now lay. Although at first dismissive of the position, Greenwood gradually came to see the possibility of taking up a chair in epidemiology and vital statistics at the newly established LSHTM as a means of having "a quiet time like other people". ${ }^{73}$ This would also enable him to intensify the work in experimental epidemiology which he had been doing at the School with W W C Topley since the early 1920 s. $^{74}$

Greenwood's move to the LSHTM at the beginning of 1927 meant that Fletcher had now to deal with the problem of Brownlee directly. In a memo to the members of the MRC Council of 15 March 1927, Fletcher argued that if the Council transferred its annual $£ 2,000$ grant for the work of the Statistical Committee to the new department at the LSHTM it would gain valuable room at the Institute in Hampstead, extra resources in the form of work by post-graduates, and improved recruitment to the field. If this happened, Brownlee's Department would be left "in its original isolation". But the only options presented by Fletcher for its future were to remove it as well, or to discontinue it at a suitable opportunity. The Department cost $£ 3,500$ per annum to run, and occupied valuable space which could be used for a laboratory, and as a board room for the Council. Fletcher noted that Brownlee was

\footnotetext{
${ }^{69}$ Report of the MRC, 1924-1925, London, HMSO, 1925, p. 42.

${ }^{70}$ PRO FD 1/7114 Memo. from Fletcher to the MRC Council dated 20 February 1925; PRO FD 1/7108 Statistical Committee, Vol. II: 'Memorandum on Organisation'.

${ }^{71}$ PRO FD 5/91 Letter from Greenwood to Fletcher of 7 January 1920.
}

\footnotetext{
${ }^{72}$ Ibid. Letter from Greenwood to Fletcher of 27 December 1922, and letter from Fletcher to Greenwood of 5 January 1923.

${ }^{73}$ Ibid. Letters from Greenwood to Fletcher of 29 July 1924 and 1 December 1926.

${ }^{74}$ PRO FD 2/9 Annual report of the MRC for 1922-23, pp. $115-16$.
} 
due to retire in June 1928, and added, "The question whether the Council will continue him for a further period or not is obviously closely connected with the questions of general policy now laid before them". ${ }^{75}$ Plainly Brownlee was being set up for a fall but before any action could be taken he died suddenly on 20 March of broncho-pneumonia. With the "old thing" out of the way, Fletcher was able to amalgamate the Committee's staff and that of the Statistical Department as the MRC's Statistical Unit under the leadership of Greenwood at the LSHTM. Greenwood was to remain head of the Unit till 1945, and chaired the Statistical Committee until $1948 .^{76}$

The establishment of the Statistical Unit at the LSHTM placed the fledgling discipline of medical statistics in an institution in intimate contact with the central state. In the inter-war period over 40 per cent of the School's students were from the colonial, military, and other government services, ${ }^{77}$ whilst government departments appointed approximately a third of the members of the School's Court of Governors and Board of Management. ${ }^{78}$ The Statistical Unit sat in a broader Division of Epidemiology and Vital Statistics which undertook work for a number of government bodies, such as the Ministry of Health, Colonial Office, and Industrial Health Research Board. In this, however, it was only mirroring the activities of other divisions of the School, which either undertook research for Whitehall departments, or drew on the staff of the latter for teaching purposes. ${ }^{79}$

\section{Medical Statistics in the Inter-War Period}

Greenwood and Fletcher now held the reins of research in medical statistics firmly in their hands, a sway which even extended to the work of the GRO. In the early 1920s the line of demarcation between the GRO's research activities and those of the ever expansive MRC had not been settled. Informally the Ministry of Health and the subsumed GRO were supposed to be concerned with aetiology, "field enquiries", and applied or health related research, and the MRC with experimental clinical and laboratory work. Friction between the two bodies, however, led in January 1924 to the signing of a Treasury brokered "concordat" designed to avoid the duplication of expensive research effort. Under this, Health was to be concerned with "applied research" relating to clinical problems, and the MRC with initiating and organizing all new research in the basic biomedical sciences. The statistical work of the Ministry, expressly including the GRO, was to be, "To survey by statistical or other means existing states of national (and international) health and environment, both absolutely and in relation to past history." The MRC's sphere was, "Medical research by statistical and other methods (primarily for the development of new

\footnotetext{
${ }^{75}$ PRO FD 1/7107 Memo. from Fletcher to the members of the MRC Council of 15 March 1927.

${ }^{76}$ PRO FD 2/13, Report of the MRC, 1926-1927, pp. 41-2.

${ }^{77}$ Report to the Court of Governors on the work of the School for the year ended 31 July
}

1936, London School of Hygiene and Tropical Medicine, 1936, p. 17.

${ }^{78}$ See, for example, Report to the Court of Governors on the work of the School for the year 1936-37, London School of Hygiene and Tropical Medicine, 1937, pp. vii-viii, ix.

${ }^{79}$ Ibid., pp. 11-61. 


\section{Edward Higgs}

methods of statistical enquiry)." This was further refined in an undated memorandum on the 'Co-ordination of functions of the Ministry of Health and of the Medical Research Council', which stated that

The Ministry must chiefly use established methods for statistical inquiry. The MRC aims at improving methods of inquiry or finding new mathematical weapons. The MRC has also to bring statistics in new ways to assist laboratory and clinical research ${ }^{80}$

The GRO was restricted, therefore, to the rather plodding work of constructing and analysing a single time series with simple methods, whilst the MRC could proceed with applying the innovations of Pearsonian statistics to medical research.

The range of activities undertaken by the staff working under Greenwood at this date was extremely wide. In 1931/32, for example, Greenwood himself was studying the epidemiology of disease in populations of mice with Topley. His subordinates, meanwhile, were working on: whooping cough mortality; anthropological data on pre-school children; the vitamin content of butter; birth rates in Wales and the southwest division of England in the period 1860-1930; mortality from pulmonary tuberculosis in Wales; the insulin treatment of diabetes; the mathematical analysis of intelligence tests; data collected by the MRC's Dental Committee; the relationship between the brain cortex and speech; and how children's different physical types affected their liability to particular diseases, such as asthma and rheumatism. Greenwood's Unit had also given assistance to the MRC's Committee on Industrial Pulmonary Disease and the School Epidemics Committee, as well as to the Industrial Health Research Board. ${ }^{81}$

A month after the signing of the concordat between Health and the MRC, the GRO began to be brought into the orbit of the latter by the appointment of T H C Stevenson to the Statistical Committee. ${ }^{82}$ Stevenson did not attend the Committee's meetings very often but when he died in 1931 Greenwood offered to replace him temporarily as the GRO's medical statistician. ${ }^{83}$ His reasons for doing so were twofold. First, as he explained to Fletcher, he feared that Newman was about to discontinue the Ministry of Health's grant to his Unit, "Hence in order to safeguard the position and knowing that there was no suitable candidate for Stevenson's post I wrote personally to Vivian offering to act for him without payment". Secondly, he saw the possibility of bringing, "the whole scientific control of the public vital statistics under the MRC". ${ }^{84}$ This situation continued until the end of 1933, when Percy Stocks was appointed as medical statistician at the GRO. Stocks was, in his turn, appointed to the Statistical Committee. ${ }^{85}$

\footnotetext{
${ }^{80}$ PRO FD $1 / 1374$ Ministry of Health and MRC_Policy. Pt 1: Concordat of 22 January 1924, and undated memorandum.

${ }^{81}$ PRO FD 2/18 Report of the MRC, 1931-1932, p. 113. For Greenwood's earlier collaboration with Topley, see PRO FD $2 / 9$ Annual report of the MRC for 1922-23, pp. 115-16.

${ }^{82}$ PRO FD 1/7114 Letter from the Registrar General to Fletcher of 25 February 1924.
}

\footnotetext{
${ }^{83}$ PRO FD 1/7109 Statistical Committee, Vol. III: letter from Greenwood to Fletcher of 11 June 1931.

${ }^{84}$ Ibid. Letter from Greenwood to Fletcher of 25 September 1931.

${ }^{85}$ PRO FD 1/7110 MRC Statistical

Committee: Report, including anaemia and measles, 1933-1936: minutes of the meeting of 26 October 1934.
} 
By this date Fletcher had died, but Greenwood was now firmly ensconced in the MRC's decision-making networks. He was also proving useful to the Ministry of Health, especially in deflecting criticism of the Ministry's response to unemployment during the Depression of the 1930s. Faced with claims that there was a health crisis in the depressed areas, the Ministry's line was generally upbeat. Newman noted in the Annual reports of the chief medical officer that the depressed areas had a worse mortality experience than the country as a whole but that they had still partaken in the general decline in death rates since the early $1920 \mathrm{~s} .{ }^{86} \mathrm{He}$ concluded that emergency relief measures were preventing a mortality crisis in these districts. ${ }^{87}$ Newman's arguments here had been supplied to him by Greenwood, who also "inspired" subsequent articles along similar lines in the British Medical Journal and the Lancet. ${ }^{88}$ Greenwood, it should be noted, actually believed that poverty caused ill-health, and was a founder member of the Socialist Medical Association. ${ }^{89}$

In addition, Greenwood and Isserlis met civil servants at the LSHTM in October 1933 to consider the effect of unemployment on mortality. According to Greenwood's account of the meeting, its purpose was somewhat negative, i.e., "To provide the departments concerned with considered reasons why the problem was insoluble, if, in the opinion of the Conference it should prove to be so". A joint committee of the MRC, GRO and Ministries of Health and Labour was set up to consider the issues involved in more detail. ${ }^{90}$ This led to the production in 1935 of a report by $\mathrm{E}$ Lewis-Faning, a member of Greenwood's staff, for the MRC Statistical Committee. ${ }^{91}$ The paper also formed the basis of an article in the British Medical Journal in 1937,

\footnotetext{
${ }^{86}$ For examples of claims of a crisis, see $\mathrm{F}$ Brockway, Hungry England, London, Gollancz, 1932; A Hutt, Condition of the working class in Britain, London, M Lawrence, 1933. For Newman's defence of the Ministry, see On the state of the Public Health: annual report of the chief medical officer of the Ministry of Health for the year 1932, London, HMSO, 1933, pp. 16-43; On the state of the Public Health. Annual report of the chief medical officer of the Ministry of Health for the year 1933, London, HMSO, 1934, pp. 206-21; On the state of the Public Health. Annual report of the chief medical officer of the Ministry of Health for the year 1934, London, HMSO, 1935, pp. 15-17.

${ }^{87}$ Newman's argument has been attacked by Charles Webster, who argues that the measures taken were generally ineffective: $\mathrm{C}$ Webster, 'Health, welfare and unemployment during the Depression', Past and Present, 1985, 109: 213-29. For the modern debate over whether Newman's optimism was warranted, see, for example, C L Mowat, Britain between the wars, 1918-1940, London, Methuen, 1955, pp. 480-517; D H Aldcroft, The interwar economy: Britain, 1919-1939, London, Batsford, 1970, pp. 375-85; J M Winter, 'Infant mortality, maternal mortality,
}

and public health in Britain in the 1930s', J. Eur. Econ. Hist., 1979, 8: 439-62; C Webster, 'Healthy or hungry thirties', Hist. Workshop J., 1982, 13: 110-29; J Stevenson and C Cook, Britain in the Depression: society and politics, 1929-1939, London, Longman, 1994, pp. 40-64.

${ }^{88}$ PRO FD 1/5073 MRC Statistical

Committee: Variations in Employment and Health: Report on Unemployment and Mortality, 1935: Greenwood's notes of a meeting with representatives of the Ministry of Health and Ministry of Labour which met at the LSHTM on 17 October 1933; PRO RG 26/28 GRO:

Population and Medical Statistics: Mortality by place of occurrence-depressed areas: letter from Vivian to MacNalty of 31 December 1935.

${ }^{89}$ On the relationship between poverty and mortality, see Greenwood's comments on T H C Stevenson's paper, 'The vital statistics of wealth and poverty', J. R. Stat. Soc., 1928, 91: 221. On Greenwood's membership of the SMA, see D S Murray, Why a National Health Service?,

London, Pemberton Books, 1971, p. 96.

${ }^{90}$ PRO FD 1/5073 Greenwood's report to the MRC Statistical Committee of 8 July 1933.

${ }^{91}$ Ibid. Report by E Lewis-Faning forwarded to the MRC on 6 December 1935. 


\section{Edward Higgs}

and of a published Ministry of Health report in the following year. ${ }^{92}$ Lewis-Faning used correlation coefficients to show that in areas where unemployment was highest, mortality was also highest, but that there appeared to be no correlation between changes in rates of unemployment and changes in rates of mortality. He concluded, following the Newman line, that, "We think that the result is that no practically important relation between the variables [increases in unemployment and mortality] has been established .... on the whole, the efforts of local and central authorities to meet the necessities of the time have been adequate and such dangers to the public health as wide-spread unemployment involved have been averted" ${ }^{93}$ The GRO was undertaking similar statistical investigations, and reaching similar conclusions, at the same date..$^{4}$ In his later papers Lewis-Faning compared age specific mortality rates of the depressed areas in England and Wales for the periods 1911-13, 1920-2, and 1930-2, stressing that the depressed areas appeared to have been unhealthy places throughout the inter-war period, and that this was probably due to "genuine geographical and racial factors". 95

The relationship between the MRC's Statistical Unit and Whitehall was deepened and widened during the Second World War, in stark contrast to Brownlee's rather ineffectual contribution to the war effort a generation earlier. ${ }^{96}$ Greenwood undertook work for the Ministry of Home Security on assessing the effects of bombing on the civilian population, and the protective value of shelters. He was also the MRC representative on a committee appointed by the Admiralty to inquire into the utilization of naval medical statistics, and a civilian consultant on medical statistics to the Royal Navy. Bradford Hill meanwhile was attached full-time to the Ministry of Home Security's Research and Experiments Department, directing the analysis of casualty rates. As the bombing offensive slackened in 1942 he moved on to the Medical Directorate of the RAF, working on measurements of the function of night vision; psychological tests for the selection of air crew; and psychiatric problems relating to flight. He also helped the MRC's Military Personnel Research Committee analysing data on road accidents involving Army vehicles; remedies for sea and air sickness; the measurement of tank personnel with regard to the design of tanks; and the statistical analysis of tank casualties. Lewis-Faning worked on problems of

\footnotetext{
${ }^{92} \mathrm{E}$ Lewis-Faning, 'A study of the trend of mortality rates in urban communities of England and Wales, with special reference to depressed areas', Br. med. J., 1937, i: 865-7; E LewisFaning, 'A study of the trend of mortality rates in urban communities of England and Wales, with special reference to "depressed areas", Rep. Public. Health. Med. Subj., No. 86, London, HMSO, 1938.

${ }^{93}$ PRO FD 15073 Report by E Lewis-Faning forwarded to the MRC on 6 December 1935, p. 54.

${ }^{94}$ PRO RG 26/28 Dr Percy Stocks' report on 'Tuberculosis mortality in the urban and rural districts of Glamorgan and Monmouth' and 'Mortality in the special areas specially affected by industrial depression (1st Schedule, Part I and
}

1934 Act) in 1934 compared with 1911-1914 and 1924, and with England and Wales, etc.'.

${ }^{95} \mathrm{E}$ Lewis-Faning, 'A study of the trend of mortality rates in urban communities of England and Wales, with special reference to depressed areas', Br. med. J., 1937, i: 867. Lewis-Faning's arguments were attacked by $\mathbf{R}$ M Titmuss, Birth, poverty and wealth, London, $\mathrm{H}$ Hamilton Medical Books, 1943, pp. 52-3, 59-60, 76.

${ }^{96}$ The importance of the two world wars in the development of the relationship between science and the state has been stressed by, for example, Gowing, op. cit., note 11 above; Gummett op. cit., note 11 above; McGucken, op. cit., note 11 above, pp. 155-264; Ronayne, op. cit., note 11 above, pp. 10-12, 16-18. 
wartime diets, and for the War Wounds Committee. Other colleagues took part in studies of the efficiency of men working under conditions simulating tropical climates; analysed the incidence of peptic ulcers for the War Office; and looked at the effects of air disinfection by aerosols on the common cold in war factories. ${ }^{97}$ Medical statisticians thus contributed to that application of scientific rationality to warfare which has been such a feature of the modern period. ${ }^{98}$

Given the closeness of the Statistical Unit's relationship, and that of the School in which it sat, with Whitehall, and the MRC's long-standing function of supervizing clinical trials, it was understandable that the Ministry of Health should turn to the Unit in 1946 to undertake controlled trials on streptomycin. This drug had been developed in the USA in 1944 for the treatment of tuberculosis, but the Treasury was unwilling to allow scarce dollars to be used to buy more than a small amount until its efficacy had been conclusively proved. Bradford Hill used a random number table to distribute 107 patients aged between 15 and 30, and suffering from a similar type of tuberculosis, to two groups - 55 to a streptomycin group, and 52 to a control group receiving bed rest only. Four of the patients receiving the drug and 14 of the control group died, a difference significant at the 99 per cent confidence level. This trial immediately received international acclaim but in the context of the present argument it is more revealing that statistical proof was now being accepted within Whitehall as justification for the disbursement of hard cash. ${ }^{99}$

\section{Conclusion}

This article has attempted to explain an aspect of the institutional development of medical statistics in Britain in the early twentieth century. The story told here has been that of how the fledgling science of medical biostatistics gained official support via the personal networks and tactical alliances which Major Greenwood forged during his career. In this he was more successful than men of greater intellectual gifts such as Karl Pearson, partly because, as he put it, "a natural inquisitiveness leads me to take interest willingly in other people's problems and to work quite hard in helping to solve them." 100 The mixture of personal influence, luck, Whitehall politics, and military utility, which helped Greenwood build and sustain the institutional structures he thought necessary, will be familiar to modern scientists everywhere. Nor was the help which the MRC Statistical Unit provided to the Ministry of Health in the inter-war period necessarily a dubious use of science. The relationship between unemployment, poverty and mortality was, and is, complex, and it was perfectly legitimate to point out some of the methodological limitations

\footnotetext{
${ }^{97}$ PRO FD 2/26 Report of the MRC, 1939-1945, pp. $326-8$.

${ }^{98}$ A Giddens, The nation-state and violence, Cambridge, Polity Press, 1987, pp. 236-42.

${ }_{99}$ Thomson, op. cit., note 22 above, pp. 239-40; Matthews, op. cit, note 1 above, pp. 115-40. See also, Alan Yoshioka, 'Streptomycin, 1946: British central administration of supplies of
}

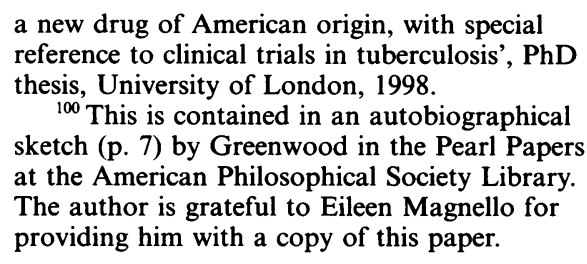

a new drug of American origin, with special reference to clinical trials in tuberculosis', $\mathrm{PhD}$ thesis, University of London, 1998.

${ }^{100}$ This is contained in an autobiographical sketch (p. 7) by Greenwood in the Pearl Papers at the American Philosophical Society Library. The author is grateful to Eileen Magnello for providing him with a copy of this paper. 


\section{Edward Higgs}

of the Ministry's critics. ${ }^{101}$ The inadequacies of Lewis-Faning's explanation for the high mortality rates in the depressed areas is perhaps more obvious to us today than it was to contemporaries. ${ }^{102}$ However, one may question whether the close working relationship between the Statistical Unit and the Ministry, which was so useful to the former, would have survived if its research had not supported the official line.

The respective fates of Greenwood's Unit and of the GRO, in the early decades of the twentieth century, also say something about the nature of research. The GRO was a government department working within the confines of a particular piece of legislation. It had comparatively little freedom to pursue new lines of research, or to experiment with new forms of statistical manipulation. This was the sort of activity which university-based researchers could carry out. The salvation of the Office in the 1930s and 1940s lay in "buying in" expertise from outside, either in the form of the statistical skills of Stocks, or of the survey methodologies of the Government Social Survey Department during the Second World War. ${ }^{103}$ This vindicates Greenwood's decision to leave the Ministry of Health in 1920. Such considerations also add some weight to the argument that Whitehall politics in the twentieth century acted as a break on statistical development within government. But what the GRO lost, however, the MRC and Greenwood gained.

\footnotetext{
${ }^{101}$ Even the influential 1980 Black Report into social inequalities in health was uncertain as to the exact mechanisms underlying the relationship: $\mathbf{P}$ Townsend, $\mathbf{N}$ Davidson, and $\mathbf{M}$ Whitehead (eds), Inequalities in health, London, Penguin, 1988, pp. 5-6.

${ }^{102}$ The effects of latitude on mortality levels was a stock-in-trade of interwar medical statistics: Registrar General's statistical review for 1932, London, HMSO, 1935, pp. 32-8; Registrar General's statistical review for 1934, London, HMSO, 1936, pp. 150-5.
}

\footnotetext{
${ }^{103}$ Stocks introduced the use of correlation and regression analysis into the GRO's reports: Registrar General's statistical review for 1934, op. cit., note 102 above, pp. 150-5. In moving into collecting data on morbidity during the war to facilitate the central planning of health care, the GRO drew upon the expertise of the Wartime Social Survey: PRO RG 26/24 Sample Survey of Sickness $1943-45$ conducted by the Wartime Social Survey: initial planning and development.
} 